\title{
IN ABSENTIA TRIALS AND THE RIGHT TO DEFEND: THE INCORPORATION OF A EUROPEAN HUMAN RIGHTS PRINCIPLE INTO THE DUTCH CRIMINAL JUSTICE SYSTEM
}

\author{
Evert F Stamhuis*
}

In a case against the Netherlands the European Court on Human Rights gave an interpretation of a provision in the Convention that amounted to the recognition of a defence right that was historically and systematically alien to Dutch criminal procedure. The Dutch criminal justice authorities had to respond to implement that recognition in the domestic justice administration. Besides explaining the intricacies of the Dutch trial in absentia, very often considered in comparative studies to be a rather odd feature of Dutch law, this article provides an interesting demonstration of the process of transplanting foreign legal ideas.

\section{INTRODUCTION}

Where legal systems meet they have a certain influence on each other. The encountering of legal systems in the world can have different appearances. Not only do systems from different domestic jurisdictions meet each other, national systems may also meet with an international system. The continuing process of internationalisation in the field of criminal law and procedure causes this type of encounter to increase, but its development could already be discerned in the situation of an active international court system for the protection of fundamental rights. This is happening in Europe on a very

* Senior Lecturer in Criminal Law and Procedure, Faculty of Law, University of Groningen, The Netherlands. Email address: e.f.stamhuis@rechten.rug.nl.

This is a revised version of a presentation given to the Faculty of Law, University of Western Ontario, London Ontario, Canada on 22 January 2001 as a Visiting Professor of Comparative Criminal Law. 
regular basis where the European Convention on Human Rights includes a procedure for individual complaints. Individuals have the right to bring cases before the European Court on Human Rights to challenge the application of domestic law in their cases. This application of Convention standards to domestic practices is a very strong example of an encounter that has far-reaching effects, especially for the domestic system. ${ }^{1}$ One could choose between two medical metaphors to characterise the effects: contamination or transplantation. The latter leads to a better understanding of the effect itself and of the response of the affected system. It is better to visualise that response as a process of incorporation of transplanted tissue rather than as the fighting of an infection. ${ }^{2}$

The first part of this paper will deal with the main aspects of the Dutch trial in absentia and its historical roots. Part III looks to the "foreign" source of the tissue to be incorporated, the European Convention on Human Rights. The case of Lala $v$ The Netherlands and its sequel in the Dutch justice administration is discussed extensively in Part IV.

\section{TRIAL IN ABSENTIA}

The Dutch Code of Criminal Procedure, dating from 1926, deals with two types of trial: a trial that takes place in the presence of the accused, called contradictory, and a trial in absentia. This straightforward approach promotes a dichotomous trial practice in the courts and facilitates a clear regulation for execution of sentences. A sentence after a contradictory trial becomes enforceable after 14 days unless an appeal is lodged. A sentence after a trial in absentia reaches the same status in 14 days in those cases where the defendant was aware of the trial day, and otherwise after a period of 14 days from the moment the defendant became aware of being sentenced. As a result a vast majority of sentences is enforceable after 14 days, a situation very convenient for further processing the case to the execution stage. On a predictable timetable the case can be produced to the agencies responsible for the execution.

When a trial is held in the absence of the defendant the court is not relieved from its duty to weigh the evidence. As the Dutch system focuses on the substantive truth to be found by an active court, a conviction can be based only on the court's assessment of the facts. The only difference from a contradictory trial is that the defendant cannot be interrogated and will not oppose any position taken by the prosecution. Since a vast majority of cases rely on documentary evidence only, the absentia trial comes down to a

1 See for a general discussion of the effects in the Netherlands: Bert Swart "The European Convention as an Invigorator of Domestic Law in the Netherlands" (1999) 26 Journal of Law and Society, 38-53.

2 Medical metaphors are also used by T Prakken Beginselen van een goede verdediging [Principles of Good Defence] (Deventer, Gouda Quint, 1999). 
brief summary of the evidence as the court has found it in the file and a sentence recommendation from the prosecution after which sentence is pronounced. In many cases even the evidence summary is left out.

Trial in absentia can take place only when certain formalities have been observed. The statutory notification procedure is the most important of these. ${ }^{3}$ At the commencement of the trial the court must satisfy itself that the prosecution has followed the provisions of the Code for notifying the defendant of the charges and of the trial place and date, but only when the defendant is absent from the court room. However, a statutorily valid notification does not always substantiate the fact that the defendant has actually received the message and is aware of the trial day. A valid notification, though without certainty about the defendant's awareness of at least the existence of the message, is constructed when the responsible officer has tried to leave the message at the registered address or other residence known by the authorities but did not succeed. When there is no registered address or other residence known, a notification can also be valid without any actual prospect of result. The latter option is justified when the defendant has failed to report his residence to the authorities. In such circumstances the authorities could not be held responsible for not being able to find the defendant for notification purposes.

It should be noted here that the Dutch do not have an active system of bail, so defendants who are not under a custody order (considerably more than $50 \%$ ) have no separate duty to report to the court or be available for service of summons. Liability for breach of bail is not a feature of Dutch law. There is only the general duty to report one's residential address to the municipality for registration. A certain distribution of obligations in this respect is acceptable under article 6 ECHR, as the European Court on Human Rights observed in Collozza $v$ Italy. ${ }^{4}$ In sum, the formalities necessary for the start of an absentia trial very often result in proof of the fact that the defendant is aware or could have been aware of the trial, but not always.

To understand the present situation a short excursion into the past is necessary. The historical roots of the Dutch position to the trials in absentia in the current Code are described as a mix of various principles. ${ }^{5}$ The adage contumax pro confesso habetur (an absconder may be held to have confessed) had some influence early in the period that was crucial to the development of the Dutch criminal procedure $(1813$ - 1886). Later in that

3 Many details have been omitted. For further information, the notification procedure can be found in arts 585 - 590 of the Code of Criminal Procedure and has been subject of many studies, for example Lameris-Tebbenhoff-Rijnenberg 1997, see below n 8.

4 Collozza v Italy (1985) European Court on Human Rights Series A 89; (1985) 7 EHRR 516.

5 Summarised from G Knigge "Van afwezend gebleven beklaagden" [To Defendants Who Stay Away] in Groninger Opmerkingen en Mededelingen IX (1992) 74-115. 
period the inquisitorial search for the substantive truth became more relevant, expressed in the rule nemo inaudita causa damnari potest. It was in the interest of the search for the truth, that the defendant was to be present at the trial, but only for the more serious cases which posed a risk to the life or liberty of the defendant. In the case of less serious offences the personal presence of the defendant was desirable but not necessary. Consequently, sentences in serious cases handed down after a trial in absentia were not executed, and the defendant retained a right to an opposition and rehearing of the case. When a defendant wanted to oppose the charges after trial in absentia an opposition could be filed and thereby render the whole absentia procedure and the sentence based on it null and void. For the less serious offences that was considered not to be necessary and those sentences became final and enforceable after a certain period of time, unless the defendant lodged an appeal. In that category the civil approach was dominant. The civil trial in absentia showed a distribution of risks and obligations. The requesting party carried the risk for the fulfilment of all the formalities for opening the trial. The absent defending party carried the risk of being held liable without being heard.

The distinction between categories of cases disappeared in 1886 and the regulation of the trial in absentia became a merger of the two preceding systems. That left the criminal procedure with a rather civil balance of interests in which the trial could go ahead without a defendant being present, as was formerly the case in the lower category, combined with the close connection of the absentia trial with the option of opposition from the higher category. The system became very generous to the absent defendant, granting in effect four instances of fact: trial in absentia and trial after opposition in both instances. The only disincentive for staying away from the trial was that the defendant had to pay the costs of the absentia trial when an opposition was lodged. This was but a weak echo of the earlier idea that staying away from the court was a separate offence to be punished in the absentia trial, not unlike a breach of bail, an offence that has never had a strong presence in Dutch procedural history. In the decades around the end of the 19th century, the practice resulting from this generosity was called the "opposition plague".

A range of budget cutting policies, implemented in 1935, affected this practice. The arrangement was changed by a statutory operation. The opportunities for the opposition were considerably reduced and the primary remedy for all persons sentenced in first instance became an appeal, also resulting in a full rehearing of the case, evidence, defences, mitigating circumstances, everything included. But the procedural arrangements of the absentia trial were left untouched. Consequently an absentia conviction and sentence could become final and enforceable under limited circumstances, derived from the existence of the right to appeal. In short, when the documents proved that the defendant had remained inactive although he or she knew or reasonably could have known of the sentence, the appeal period expired and the sentence could be executed. In many cases that 
was very shortly after the pronouncement of sentence, because the documents proved that the pre-trial notification had resulted in the required knowledge of the trial and thus of the date of sentence. In these cases the law made no distinction between absentia and defended trials. Sentence became final after 14 days, unless an appeal was lodged. The bureaucratic processing of cases could easily be designed with this clear and predictable arrangement. Only a small minority of cases were under appeal. Another minority of cases remained pending because there was no indication of the defendant's knowledge that could set off the appeal period. The rest could go through to the executing agencies. The convenience of this arrangement became all the more precious after the rise of the numbers of cases in the second half of the 20th century. Clarity as to the finality of the disposals and as few pending cases as possible reflect the managerial values that dominated the processing of cases in the courts.

A cornerstone of the system was the personal presence of the defendant. The historical reluctance to accept an absentia trial as final was based on it. The generous opportunities for an opposition also showed the idea that when a trial in presence of the defendant could be held that was to be preferred over an absentia conviction. It was therefore only under very limited conditions that the defendant's presence could be replaced by the presence of an attorney. The Code granted this opportunity only in the very small number of cases in which there was no liberty risk at all. Only a few offences did not carry a certain custody risk and fell in this category. Then the interest of a proper adjudication did not require the personal presence of the defendant. When in those instances an attorney was admitted instead of the client, it was a situation of replacement more than of representation. Legally the attorney became the defendant. The attorney's declarations could be used as evidence and procedural rights were defined as if the attorney was the defendant in person. So, in the Code the attorney's position was but a derivation of the client's and in no way did the attorney have a right or title to appear, nor to represent the absent client in a regular case. The defence attorney had no right to address the court, so when the client remained away the attorney could stay at home as well. The only business for the attorney in court would be to observe the trial in absentia and hear the final outcome of the case.

From all this the conclusion can be drawn that the absentia trial regulation was not built on pillars like the right to defend oneself with the assistance of counsel, a right that could be subject to a waiver according to the appreciation of the defendant. Even a right to be present at one's trial was not explicitly recognised as such, either in the Code or in the European Convention. ${ }^{6}$ The European Court on Human Rights included that right in the

6 Article 14(3) (d) of the International Convention on Civil and Political Rights recognised the right to be present at trial. 
Convention by way of interpretation in its Colozza judgment in $1985 .^{7}$ Some elements of the described system could be reframed in terms of these rights, but that might cause some tension. ${ }^{8}$ Important now is that the concept of rights and the connected possibility of a waiver was not the ruling framework in the Dutch system at that time.

The rather rigid approach to the position of the defence attorney was ameliorated to a certain extent by the courts in cases where it was obvious that the defence wished to contribute to the trial but the defendant was unable to come to court. The lower courts adopted the policy that when the defence attorney appeared in the courtroom and satisfied the court that the client really could not come although was willing to do so, this attorney was granted the opportunity to speak on behalf of the defence. The criterion "really could not come" was expressed in the requirement of "compelling reasons". One example of compelling reasons was the defendants having professional duties that were incompatible with appearing in court on the trial day or any other day in the near future, like fishermen at sea or engineers at an off-shore installation. Another example was the defendant being impaired by bad health, being bedridden or housebound for the foreseeable future. A motion for acknowledgement of compelling reasons usually implied that the defendant preferred the case to be dealt with in their absence rather than applying for an adjournment. As before, the courts were at liberty to order the appearance in person of the defendant if it held that to be in the interests of a proper adjudication of the case. That could not be done without an adjournment, causing considerable delay.

Obviously, the decision of the court to accept the defence attorney conducting the defence for an absent client comprised a balance of various interests: (a) The presence of the defendant for observation and interrogation by the court systematically, weighs heavily; (b) The opportunity for the defendant to respond to new developments in the case may require an adjournment after all, which would render the first proceeding a waste of court time; (c) The need to hear and decide the case without undue delay was stressed by the Supreme Court's case law on the reasonable time requirement of article 6(1) of the European Convention on Human Rights; (d) The efficiency and expediency of the court planning required the avoiding of adjournments as much as possible. When the court decided that the defence attorney could speak, the trial remained within the category of absentia. However, from the presence of the attorney one could conclude that the defendant knew where and when to stand trial. The sentence could be held to become final after 14 days unless an appeal was lodged. So, for the execution of the sentence no new

Collozza v Italy, above n 4.See also FCB v Italy (1991) ECHR 28-08-91 Series A 208-B.

8 See for a critical study of the Dutch system from this perspective HME Lameris-Tebbenhoff Rijnenberg, Dagvaarding en berechting in aanwezigheid [Notification and trial in presence] (Amsterdam: Thela Thesis, 1997). 
problems arose for the processing of the case in the criminal justice bureaucracy. The acceptance by the Supreme Court of this practice completes the historical excursion, so now we can turn to the present.

\section{THE EUROPEAN CONVENTION ON HUMAN RIGHTS, ROME 1950}

What we have so far is a systematic framework in which the trial in absentia could be understood as concordant with the basic principles and values of domestic law. It could only occur when there was evidence that the defendant was aware of the date and place of the trial or evidence that the authorities had discharged their duty to take all reasonable steps to notify the defendant of that date and place. The defendant's wish to be tried in absentia could be derived from all these circumstances and therefore the defendant's rights were not violated. Trial in absentia was also not an impediment to the purpose of gaining certainty as soon as possible as to the finality and enforceability of the sentence, a purpose firmly backed up by managerial values in the Dutch criminal justice administration. But now we have to pay some attention to the principles and safeguards under the European Convention on Human Rights, also known as the Treaty of Rome $1950 .{ }^{9}$

The Dutch domestic law meets with the law of the Convention through the monistic provisions in the Dutch Constitution Act (Grondwet) relating to law originating from international relations; article 93 in particular. Treaty provisions as well as decisions from international organisations can become part of the law of the land, provided that they are self-executing and as soon as they are properly announced. There is a lot more that could be said about that but it would take us beyond the subject-matter of this article. Important for now is the fact that the provisions relating to fundamental rights in the European Convention are part of Dutch law and that the Netherlands have recognised, as have many other member states of the Council of Europe, the right for individuals to bring complaints before the European Court on Human Rights in Strasbourg. The encounter of the two systems, the Dutch domestic law and the Convention's system of fundamental rights protection, can thus be viewed as an ongoing process. From time to time the Strasbourg court developed case law that gave a new interpretation of the Convention's provisions, which then had to be incorporated in the Dutch domestic law. That was not only the case in complaints against The Netherlands but also after judgments against other states, in which the Court gave a new meaning to the safeguards granted by the Convention.

Under the European Convention, article 6(3)(c), a defendant has the right to defend and to use the assistance of an attorney of his or her own choice. The Strasbourg court has added to that the right to be present at the trial in its Colozza judgment. Although not

9 See D J Harris, M O'Boyle, C Warbrick Law of the European Convention on Human Rights (Butterworths, London, 1995). 
explicitly listed in the Convention this right had to be understood as being part of the defence rights, as the Court observed. To make an effective use of all the rights in article 6 of the Convention, in which the right to a fair trial is granted, one has to have the opportunity to be present at the trial. A trial in absentia was acceptable as long as it could be understood as being a waiver of that opportunity. After proper notification the defendant knew where and when to stand trial. By not showing up the right to be present and to use all the relevant defence rights in person was waived. Even when the notification was not successful in bringing the message home to the defendant in person, a trial in absentia could go ahead. The Court formulated certain conditions for that in the same judgment. The most important conditions are, that the authorities have taken all reasonable steps to reach the defendant and that the defendant has a remedy available for fresh determination of his case.

As can be concluded from the description of the "compelling reasons" requirement, Dutch law did not leave room for a partial waiver of the rights under article 6(3)(c). A defendant was not entitled to prefer not to appear personally but let the attorney defend in place of the defendant. For lack of any compelling reason to stay away, the court would not accept that course of action and deny the attorney the opportunity to speak on behalf of the client. Reformulating this approach of the trial in absentia in terms of rights one could phrase the Dutch message to the defendant as follows: If you waive your right to be present and defend yourself, you have automatically waived the right to any defence unless you have a relevant excuse; if you prefer otherwise, you have only one option: to come to court in person thereby rendering the trial contradictory. This clear-cut bipolar approach was challenged under article 6 of the Convention in the case of Lala $v$ The Netherlands.

\section{LALA V THE NETHERLANDS}

After having been sentenced in absentia by a court of first instance a Mr Lala appealed to the Court of Appeal but did not show up at his trial day in that court. He chose not to appear because he feared arrest to serve some default detention still outstanding from another sentence. Compelling as this may have been to him personally, the Appeal Court had to consider these as legally irrelevant reasons and therefore Lala's attorney was not given any time or opportunity to defend the interests of his client before the Appeal Court. The defendant was convicted and sentenced. The complaints of Lala before the Supreme Court of The Netherlands were unsuccessful so he brought his case to Strasbourg, resulting in the Court's decision of September 22, $1994 .^{10}$

10 Lala $v$ The Netherlands (1994) ECHR Series A 297-A. 
In its observations the European Court on Human Rights found that the Dutch practice constituted a violation of article 6 of the Convention. The compelling reasons requirement represented a too narrow approach to the right to be defended by counsel. When the defence attorney arrives in the court room for the apparent purpose of defending his client, who is not present in person, the trial court must allow him to do so. To deny him that opportunity amounted to a breach of the Convention. If it was the line of defence the defendant chose to follow it was not for the trial court to interfere on the basis of a test of the reasons for this choice. The crucial passage in the court's observations said:

The fact that the defendant, in spite of having been properly summoned, does not appear, cannot - even in absence of an excuse - justify depriving him of his right under article 6(3) of the Convention to be defended by counsel.

In the court's opinion the Dutch practice did not represent a fair balance between the interests at stake:

In the interest of a fair and just criminal process it is of crucial importance that the accused should appear at his trial. As a general rule, this is equally true for an appeal by way of rehearing. However it is also of crucial importance for the fairness of the criminal justice system that the accused be adequately defended, both at first instance and on appeal, the more so if, as is the case under Netherlands law, no objection may be filed against a default judgement given on appeal. In the Court's view the latter interest prevails.

The Dutch Government had in its defence put forward an additional argument beside the lack of compelling reasons. It had stressed that the attorney of Lala failed to apply to the Appeal Court for time to speak on behalf of his client. He remained inactive though he had had the opportunity at the commencement of the trial to speak for his client. Therefore, the Government argued, it was not proper to blame the Appeal Court or any authority for circumstances that were due to the inactivity of the defence attorney in the case. The European Court rejected this argument even more firmly than it did the compelling reasons test. It held that the rights of the Convention could not be subjected to unduly formalistic requirements, such as a formal application to be granted the use of these rights at a specific hearing. That would frustrate the practical and effective use of the Convention rights. Moreover the courts had their own duty under the Convention to ensure that the rights and safeguards are respected in every trial or hearing before them.

V

INCORPORATION OF THE NEW RIGHT TO BE DEFENDED BY COUNSEL IN ABSENTIA

This judgment (and the similar judgment in the case of Pelladoah $v$ The Netherlands, issued on the same day) caused great unease among members of the Dutch legal community. Some argued that it meant the end to the vast and very efficient absentia practice and would cause a collapse in the criminal justice administration. Others tried to 
put these and other minds to rest by referring to the case bound nature of the judgments of the Strasbourg court. But everyone agreed that at least the "compelling reasons" test should be abolished. Since it was developed not by legislation but by practice, this change could be brought about very easily. From now on the courts could no longer limit the right to be defended by counsel to situations where they accepted the reasons for absence of the defendant in person. This demonstrates a first aspect of incorporation of a principle formerly rejected. The Dutch courts accepted that the new proper interpretation of "the right to be defended by counsel" in article 6(3) (c) of the Convention included the use of this right even when the defendant is personally absent. That created a hybrid form of trial in the former bipolar approach, and was in contradiction to the historical development of the Dutch system.

The Dutch Department of Justice, sharing a general responsibility for the administration of justice, and the judicial management authorities saw some problems. This new form of trial did not fit the system of the Code, particularly not in the construction for appeal periods and related enforceability. The uncertainty would hamper the efficient processing of cases through courts and from courts to executing agencies. There were a lot of questions to which there was no immediate answer available, such as:

- Should the courts in all cases declare the trial to be formally in absentia, testing the evidence for notification et cetera? Usually that test was only relevant when the defence did not appear, but now the courts were confronted with the defence having appeared only by half.

- Was it a proper practice to require written evidence of representation, especially when procedural steps required the explicit consent of the defence, such as (a) the immediate continuation of the trial after changes in the indictment or (b) the waiver of (further) interrogation of a specified witness? Special problems were to be expected in cases where the court considered a community service order, because these orders require the explicit consent of the defendant in person.

- What is the exact meaning of "being defended by counsel" in the domestic context? Is it merely a speech at the end of the trial or does it include the use of all kinds of procedural rights, such as the right to cross-examine witnesses, to apply for additional evidence from witnesses or for an additional judicial investigation? It is important to state here, that the Code does not grant separate defence rights to counsel, but only to the defendant. A provision in the Code derives the attorney's position from the defendant's procedural rights under the implicit assumption that the defendant is present at the trial when the attorney acts on the defendant's behalf in the use of these rights. 
Apart from these and other uncertainties as to the further incorporation of the new right to be defended in absentia and the hybrid form of trial that resulted, there was an additional incentive for the government to take an initiative. The Code of Criminal Procedure is perceived to strike the balance between all the relevant interests in the criminal justice administration. Now that the European Court on Human Rights had rocked the scales on one side, action was called for to restore the balance between defence interests and managerial interests of the government agencies and the courts by way of a statutory change. ${ }^{11}$ It is a dominant belief that one cannot leave the court system with the resolution of the imbalance. Not only would that pose a risk of great disparities between individual courts, it would also take a lot of time before some guidelines could be expected to arrive from the Supreme Court. Moreover, the Supreme Court would only act on a case by case basis and therefore in piecemeal way. Finally, it is all but common belief that the courts have no power to make this kind of pseudo-legislative decision. Although the judicial application of self-executing provisions of international law cannot in itself be corrected by the legislature, the framework in which a new interpretation can operate must be developed in domestic legislation. It was firmly held by the government that new legislation should be implemented to restore order and uniformity.

The Minister of Justice, responsible for drafting a Bill for parliament, seized the opportunity to rephrase the whole chapter in the Code relating to the regular course of the trial. He proposed to rewrite the scenario to adapt it to the modern court practices. The purpose was also to re-edit the Code where partial amendments in the past had resulted in textual or even legal inconsistencies. After parliamentary discussions in both Houses a new chapter was enacted, part of which was intended to complete the incorporation of the Lala principle by encapsulating it in the domestic statutory system.

The new legislation shows a determined choice for sticking to the bipolar approach to trials. There were only two forms of trial: contradictory or in absentia. In the new article 278 of the Code the court is bound to test the notification procedure when it wants to try the case in absentia, but if the legal requirements are observed the court can declare the trial to be in absentia. Additionally, article 279(1) of the Code enables the courts in these absentia cases to allow an attorney, present to defend his client, to speak on behalf of his client and take every procedural step he thinks proper. The defence attorney is able to do this through various provisions in the Code, which include the right to confidential conferences with the client. The accused is served with a copy of the notice of the time and

11 F D van Asbeck (at that time head of the responsible division of the Justice Department) used the terms: "reparation of an important imbalance" in "Belang van de verdediging, ook in verstekzaken" [The defence interest, also in absentia trials] in C J G Bleichrodt and others (eds) Mens en recht (Deventer, W E J Tjeenk Willink, 1996) 276-285, 283. 
place of the trial as well as of the charges and has a full right of access to the case file before the trial day. But, as the Code states in article 279(1), the opportunity to speak is only to be given to attorneys who appear on the basis of an explicit authorisation from their clients, not necessarily in written form but nevertheless explicit. Article 279(2) of the Code then closes the trap by reversing the absentia form of the trial into a contradictory one in every case where paragraph 1 is applied, even when there is no evidence of the defendant being personally aware of the trial date. ${ }^{12}$

What exactly is this "trap"? The formal contradictory form of the trial rules out all the problems that a trial in absentia may bring about, especially those related to appeal periods and enforceability. So, in all cases where a defence attorney shows up for the client, whether the defendant is notified in person or not, the trial has the contradictory form with all the smoothness in further processing the case that is the statutory consequence of that. This seems to be a brilliant construction to couple the domestic managerial values and demands with the principle developed in Lala. So one might come to the conclusion that the incorporation strategy of restoring a balance by way of statutory regulation proved to be successful. If it was not for those clever defence attorneys who saw the trap and refused to co-operate.

Members of the Dutch Bar found that the "contradictory" label was to a certain extent unfavourable to their clients' interests. To clarify the position let us look at the very common case where the defendant does not maintain frequent contact with the attorney, because he or she lives on the streets and has no regular life whatsoever, let alone regular attention to legal interests. Almost always a defendant like this has not reported their whereabouts to the local registry and is very likely not to be reached by the notifying officer. Then the notification procedure very often does not result in the defendant knowing where and when to stand trial, ${ }^{13}$ but the attorney is notified separately. When this attorney appears but cannot honestly say (or chooses not to say) that the client has given express authorisation to defend on that day, the court can do nothing but declare the trial in absentia. For lack of any evidence that the defendant had the necessary knowledge, uncertainty as to the date of finality of the sentence would be the consequence. The Code does not provide for a way in which the attorney can defend the client without the statement of express authorisation.

12 The statutory notification procedure does include a form that does not result in evidence of the defendant having received the message in person.

13 A separate initiative of the justice authorities is aimed at increasing the amount of succesful notifications. The necessary documents are prepared at the police station immediately after arrest and served on the accused at his departure. Consequently, the defendant knows where, when and for what charges to stand trial. That prevents lack of clarity as to the appeal period, but does not resolve the issue of the defence in absentia. 
Such defence attorneys are confronted with a dilemma in terms of the interests of the defendants they represent, a dilemma they quite rightly reject rather than resolve. Both ways can turn out to be unfavourable to the defendant. Either they use their right to speak, but then the appeal period (applicable to contradictory trials) may expire even before the client finds out what the outcome of the trial is and before there has been a real opportunity to consider an appeal. Or they remain silent and the case is dealt with in absentia form, possibly with an extended appeal period but without presentations from the defence side. This dilemma can be rejected as being contrary to Lala. When an attorney has shown up in the courtroom for the apparent purpose of defending the client, in the view of the European Court the attorney has to be given the opportunity to do so. So the statutory encapsulation construction fails after all. In order to maintain the two forms of trial, article 279 of the Code requires a statement of express authorisation from the client before an attorney is given the right to speak. Although in itself a correct construction in terms of the system of the Code, it is the imposition of unduly formalistic conditions and therefore contrary to the observations in Lala.

In sum, there are two connected factors from inside the transplanted principle that adversely affect the incorporation into the managerially beneficial system of the Code: the undue formalities factor and the dependence on co-operation from the advocacy. The statutory operation having failed at least partially, it is up to the courts to remedy the situation and develop policies that will render the Dutch practice in concordance with the European Court's interpretation of article 6(3) sub c of the Convention. Some courts of first instance have adopted the approach of granting the opportunity to defence attorney to defend a client even when the attorney cannot make any declaration as to the express authorisation, effectively ignoring article 279 of the Code. Others do not follow this line and in effect put pressure on attorneys to give statements of authorisation in view of the necessity of defence in first instance, the trial becoming contradictory as a matter of consequence. Even judges in the same court adopt different approaches from time to time. It is difficult to say that one or the other approach always results in an unfairness to the defendant, especially not under article 6 of the Convention, where fairness is the result of a delicate balance in the specific case. However, the differences can be considered to be very unfavourable to the management of the system, resulting in unpredictable delays, uncertainties and a lack of uniformity.

\section{EPILOGUE}

The aftermath of the case of Lala $v$ The Netherlands demonstrates how the Dutch system of criminal justice administration, paying large tribute to managerial values and goals, responded to the implantation of a principle that requires a certain procedural justice in individual cases under article 6 of the Convention. It shows the limits of the dominant approach trying to encapsulate the newly developed norms in statutory provisions. It 
contains to a certain extent the prediction that a more open statutory framework is better suited to incorporate principles of fairness in individual cases, finding a new balance between managerial interests of the administration and the legal interests of individual fairness.

The additional role for the courts to reach this objective should be seen not as a disadvantage but as a natural feature of a modern European system under the Convention. After the transplantation operation the patient's body is no longer the same, but the patient is in a better condition. 